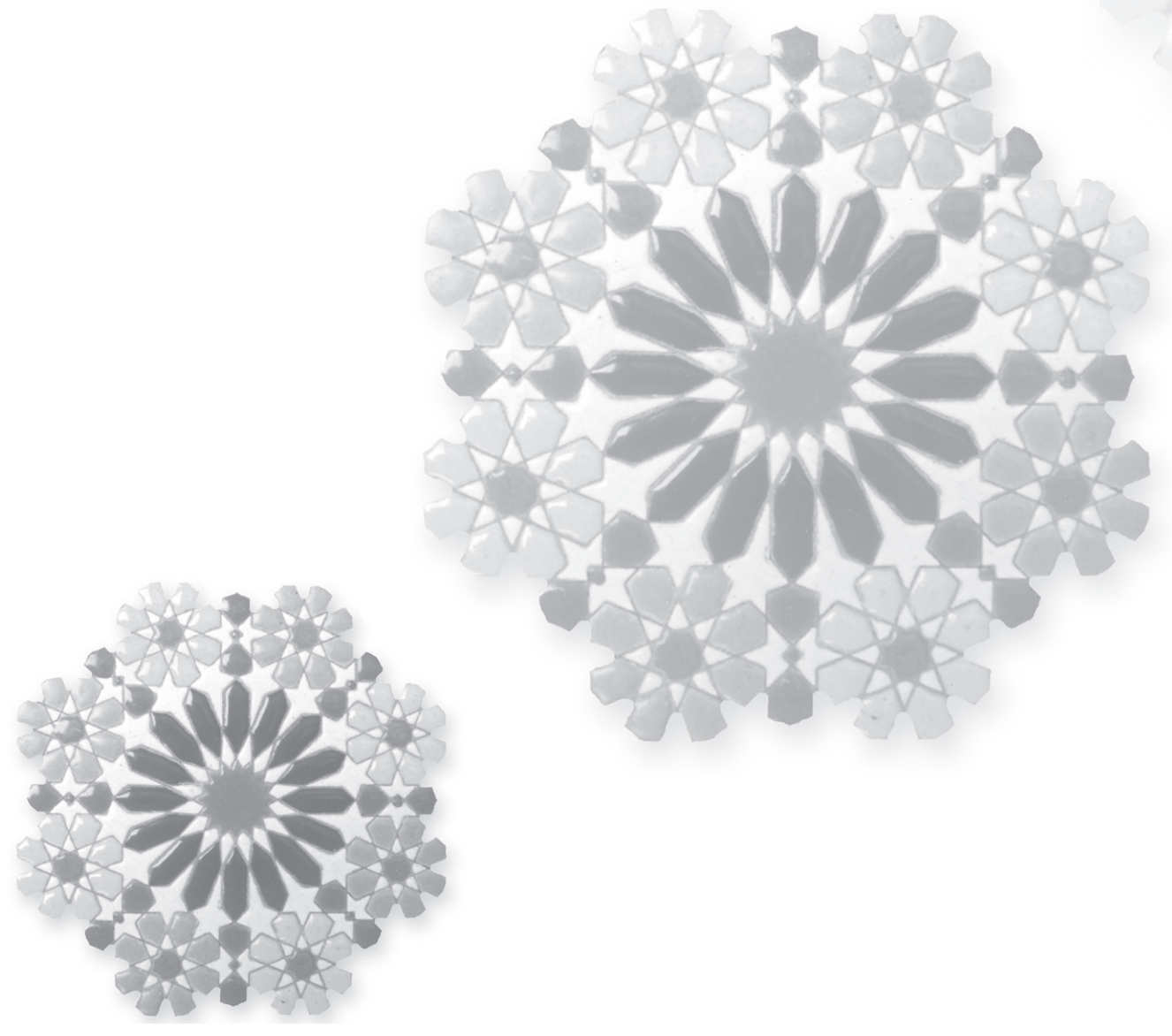




\section{Julio Tello as a medical anthropologist: assessing the antiquity of syphilis in ancient Peru}

\section{Julio Tello como antropólogo médico: examinando la antigüedad de la sifilis en el antiguo Perú}

Christian Mesía-Montenegro

Dean, School of Human Sciences/Universidad Cientifica del Sur. Lima - Lima - Peru

cmesia@científica.edu.pe
MESÍA-MONTENEGRO, Christian. Julio Tello as a medical anthropologist: assessing the antiquity of syphilis in ancient Peru. História, Ciências, SaúdeManguinhos, Rio de Janeiro, v.25, n.2, abr.-jun. 2018, p.541-552.

\section{Abstract}

This paper explores the methods used by Julio Tello to address the antiquity of syphilis in ancient Peru, examining his thesis La antigüedad de la sífilis en el antiguo Perú to understand the logic behind the procedures he used to test his hypothesis. The contention presented here is that despite being a medical thesis, his text can actually be considered an exploration of the origins of syphilis using a truly anthropological method, making Tello a pioneer in the subfield of medical anthropology in the Andes.

Keywords: syphilis; archaeology; Peru; medical anthropology; Andes

\section{Resumen}

Este artículo analiza el método utilizado por Julio Tello en la investigación de la antigüedad de la sífilis en el antiguo Perú, examinando su tesis $\mathrm{La}$ antigüedad de la sífilis en el antiguo Perú, con la finalidad de comprender la lógica detrás de los procedimientos utilizados para evaluar su hipótesis. A pesar de ser una tesis en medicina, el trabajo de Tello puede ser considerado como un trabajo en el cual se utiliza el método antropológico en la evaluación del origen de la sífilis, convirtiéndose Tello en un pionero en el campo de la antropología médica en los Andes.

Palabras clave: sífilis; arqueología; Perú; antropología médica; Andes. 
$\mathbf{I}_{e}^{\mathrm{n}}$ n 1909, Julio C. Tello published a dissertation entitled La antigüedad de la sífilis en el antiguo Perú, which argued that there was sufficient linguistic, ethnohistorical, archaeological, and osteological evidence to prove that syphilis existed in the Central Andes during prehispanic times. This work was part of the requirements to become a surgeon at the School of Medicine of the Universidad Nacional Mayor de San Marcos, but as I argue in this paper, the text can be read as a thesis on medical anthropology. Later in his career, Tello became the best-known and most prestigious archaeologist in the history of Peruvian archaeology.

The present paper highlights Tello's method, and scrutinizes his hypothesis on the origin of syphilis in the Central Andes long before the arrival of the Spaniards. Tello's work on syphilis was mentioned as a passing reference by a number of scholars (for example, Pardal, 1937) but as we shall see, it was Pedro Weiss who paid more serious attention to Tello's contributions to this particular field, coining the term "cultural osteology" for the cultural analysis of human bones (Weiss, 1961), and was clearly influenced by his work. Despite few detailed studies of Tello's dissertation, some scholars such as Lozada argue that his work

reflects a true multidisciplinary approach to diagnosis and interpretation of past diseases. Tello conducted a detailed and extensive ethnohistoric, linguistic and medical analysis of syphilis, as well as a comprehensive osteological examination of nine preColumbian crania ... After careful deliberation and a complete differential diagnosis, he concluded that syphilis was a pre-Columbian disease, an assertion that is still the subject of debate today (Lozada, 2014, p.13).

At this point, it is most likely that the most detailed analysis of La antigüedad de la sifilis en el antiguo Perú was performed by Altamirano (2013), but since this work mainly focused on paleopathology rather than Tello's anthropological method, the present paper is original and relevant.

\section{Historical anachronism}

It is challenging to address the rationality or methods used by a scholar more than 100 years ago through the disciplinary eyes of the modern context, considering that the field of medical anthropology and even the traditional four-field composition of anthropology as a discipline had hardly developed at that time. It is consequently possible to argue that Tello's thesis is an example of historical anachronism, a juxtaposition of rationalities and methods from diachronic social contexts. My understanding of anthropology as a field and particularly medical anthropology is based on formal training; from this perspective I evaluate Tello's work, which I argue can be considered an essay on medical anthropology, decades before this subfield even existed as we currently know it. For a detailed narrative of the relation between medicine and anthropology, I suggest the work of Comelles and Martines-Hernáes (1993). 


\section{Hypotheses on the origin of syphilis}

In the current understanding of the origin of syphilis, modern researchers consider three hypotheses which posit that syphilis was first documented as an independent disease in 1495 (Karem, Pillay, 2014). The first is the Columbian hypothesis, which indicates that syphilis originated in the Americas and was carried to Europe by the Spaniards, causing the 1500s epidemic (Crosby, 1969; Dennie, 1962; Harrison, 1959; Hershkovitz et al., 1994; Hudson, 1965; Knell, 2004; Luger, 1993; Rothschild, 2005). There are more complex explanations than "it originated in the New World;" for example, Harper et al. (2008) argue that a nonvenereal form emerged in the Old World before the European invasion of the New World, while the disease originated in a venereal form in the New World, and this variety was introduced into the Old World after the European invasion. The second is the European hypothesis, stating that "syphilis was in Europe prior to Columbus's voyage, but was not distinguished from leprosy" (Baker et al., 1988, p.703). The 1500s epidemic resulted from the identification of syphilis as different from leprosy (Blondiaux, Le Bagouse, 1994; Henneberg, Henneberg, 1994; Palfi et al., 1992; Roberts, 1994; Stirland, 1991). More recently, Powell and Cook (2005) concluded that there is no evidence venereal syphilis was present in the Americas (at least in North America) before the Spanish invasion. The third unitarian hypothesis states that syphilis has been a pervasive element in human populations that originated in the New and Old Worlds. Hudson (1965) championed this hypothesis, stating that since Paleolithic times there is simultaneous evolution of four treponematosis syndromes caused by Treponema pallidum, which spread in Europe and the Americas while Homo sapiens populated these continents.

The Colombian and unitarian hypotheses posit that syphilis was present before the arrival of the Spanish. My goal here is not to prove any of these hypotheses, but rather to shed light on the methods Julio Tello used to prove his own hypothesis that syphilis was present in the Andes before the Spanish arrived. In this regard, I argue that Tello's method was appropriate, given the somatic manifestations of the disease, in which "asymptomatic bone lesions often go undetected in early syphilis" (Baker et al., 1988, p.704), "skeletal involvement in venereal syphilis more often affects the cranial vault, the nasal area and the tibia" (p.704), and finally, "clinically, yaws and endemic and venereal syphilis closely resemble each other in the prolonged course of the disease, with early and late manifestations" (p.704). Osteological lesions are only present in the final stages of the disease, which poses a problem for identification via skeletal remains alone. In this regard, Karem and Pillay $(2014$, p.1) are correct in stating that

Limitations in assessments of the origin of syphilis include variations in the scientific method used. For example, documentation on bone lesions may provide possible evidence of syphilis in anthropologic specimens; however, these may not be exclusive to syphilis. Likewise, the variations in dating of specimens highly depend on the methods used.

As a result, it is important to utilize a wide array of transdisciplinary methods to arrive at a more accurate answer to the problem at hand; this analysis requires more than one line of evidence, as we see in Tello's work. 


\section{Tello's method}

Before becoming an archaeologist, Tello studied medicine at the Universidad Nacional Mayor de San Marcos. In 1908 he defended his thesis, which was approved with honors and published the following year (Tello, 1909). Tello was always interested in archaeology, particularly cranial deformation and its cultural significance, but decided to pursue medicine since no archaeology degree was offered in Peru at that time. This may explain the opening remark in his thesis:

Let us conduct a dissection of the more important features of this disease in order to make sure that it exists among the languages, religious beliefs, and superstitions of the ancient Peruvians, and more importantly, in the skeletons and ancient Peruvian pottery artifacts that are in their rooms and tombs (Tello, 1909, p.15). ${ }^{1}$

Tello developed four fields of analysis which include: (1) linguistic, investigating whether the ancient Andean languages contained any words that could describe any diseases with symptoms similar to those attributed to syphilis; (2) ethnohistorical, exploring whether any behavioral reason might have favored the spread of a disease through sexual intercourse; ${ }^{2}$ (3) archaeological, in an attempt to identify cultural manifestations of this disease in archaeological objects such as ceramics; ${ }^{3}$ and (4) osteological, searching for signs of the last stages of the disease in archaeological bone remains. Incidentally, these lines of evidence represent a traditional four-field anthropological approach.

Let us now examine the evidence recovered for each of the stages described above.

\section{Linguistic}

In 1903, Albert Ashmead wrote "these images were idols, and these representations were the expressions, as I defined it, of the disease, syphilis, before those ancient cultures in Peru had a word for it in their language" (Ashmead, 1903, p.380) when talking about the wood figures published by Mantegazza (1886) in his L'amour dans l'humanité. When Ashmead wrote this text, he was unaware of the existence of the Quechua word huantti, which according to Tello may be related to the disease.

Tello explained that in early 1498 accounts of the word bubas appeared, meaning "smelly, damned and contagious pustules" (Tello, 1909, p.18). Tello takes this word as indicative of syphilis ${ }^{4}$ because of the account by López de Villalobos (1498) expressing that the smelly bubas appeared on the "basest spot we have," corroborating the symptoms described by early scholars who examined the Naples outbreak (Arrizabalaga, 1988; Tognotti, 2009). It is interesting that Tello did not cite López de Villalobos with regard to identification of the disease as early as 1474 in Europe. Nevertheless, Tello attempted to find a native equivalent in the early bilingual dictionaries (Quechua-Castilian and Aymara-Castilian). He found the Quechua terms huantti (bubas), huanttipcuccifcam (eaten by bubas), and huantticapa (full of bubas), among other words related to the disease (Tello, 1909, p.19-20). He also identified Aymara words such as huanthi (bubas), huanthi haque (full of bubas), and catutha (to get bubas), among other related words (Tello, 1909, p.21-22). He stated that the etymology of these terms extended to long before the Spaniards arrived, but failed to provide any evidence other than that retrieved from early dictionaries, concluding that 
Based on the slight analysis we have just made, the word huanthi in the Aymara as well as in the Quechua languages has described since indefinitely ancient times a corrosive, contagious disease, likely transmitted by the genital organs, and there is nothing to prevent this word from being identified as syphilis (Tello, 1909, p.24).

\section{Ethnohistorical}

Through ethnohistorical accounts, Tello attempted to identify any behavior that might have led to the spread of the disease in prehispanic times. Tello (1909, p.25) searched the ethnographic record for clues that promiscuous sexual behavior was responsible for this infection, and titled a chapter of his thesis "Excess and sexual aberrations in ancient Peruvians, lewd and lascivious behavior, prostitution, pederasty and sodomy." He found ethnographic accounts of actions that (in his opinion) could be identified as syphilitic vectors, including sodomy, which was punished with death during Inca times according to some accounts (Tres..., 1879). Tello (1909, p.25) paid considerable attention to citations of behavior he considered promiscuous, using early Spanish chroniclers to prove his case and stating that "Indians were generally attracted to the worship of Venus." Nevertheless, he used derogatory Spanish remarks about the sexual practices of the Incas to prove the hypothesis that Andean aboriginal people had a compulsory behavior which undoubtedly caused the spread of syphilis.

The dubious veracity of these remarks aside, their existence does not prove the presence of syphilis. In fact, they only strengthen the viability of dispersal but not the presence of the disease, leading Tello to provide an Andean myth (Avila, 1966) as evidence, in which an adulterous woman caused her husband to have a "long and filthy, dirty and disgusting disease" (Tello, 1909, p.53), a "disease transmitted by sexual contact" (p.53). Tello's logic in this line of evidence is weak and flawed as he uses circumstantial evidence that does not directly support his case.

\section{Archaeological}

Based on Alfredo Fournier's (1906) Traité de la syphilis, which argued that in its tertiary state the disease tends to affect the nose, ${ }^{5}$ Tello attempted to identify this stage of syphilis in anthropomorphic ceramics, particularly the lesion known as cranial caries sicca (Baker et al., 1988, p.712). This lesion is described as ulcerations and deformation of the nose, particularly in what we today know as Moche ceramics (c.100-500). To support his claims, he included Spanish descriptions of nasal lesions observed in the Andes: "They [the native people] have a disease affecting their noses that eats them and makes worms appear" (cited by Tello, 1909, p.103). This was not the only record cited by Tello; his work is a compendium of these types of citations. Tello began by making the case that the Spanish word uta (which today refers to the disease known as cutaneous leishmaniasis) was actually a synonym of the Spanish word llaga (sore):

This word $u t a$, in the provinces of Huarochiri and Yauyos, and in all likelihood throughout Peru, is commonly applied to any ulceration that evolves chronically. Thus, syphilitic ulcerations, tubercular ulcers, phagedenic ulcers and even varicose ulcers 
are indifferently designated by this term. This is the vulgar designation, generally to all the $u t a$ abodes, not as a specific disease, but as a simple synonym of the Spanish [word] sore (Tello, 1909, p.111-112).

In order to prove his point, Tello combined two lines of evidence mentioned previously: the anthropological proof containing early chroniclers' observations to explain that the caries sicca lesion was highly noticed by the Spaniards, and the linguistic proof stating that

it is strange that the word $u t a$ is not cataloged as a disease, in the Quechua and Aymara vocabularies, including in them the names of many other diseases. The word uta seems to be of modern creation (Tello, 1909, p.112).

My goal here is not to assess whether Tello's assertions were correct, but rather to explain the logic he used while testing his hypothesis. It is particularly interesting how he drew information from different lines of evidence even when attempting to prove one particular point or assertion.

\section{Osteological}

Tello collected skeletal remains from his native town in the highlands of Lima, in Huarochiri, more than 3,000 meters above sea level. He expanded his sample through informal archaeological excavations in thirty burial sites, examining only nine skulls. Before addressing the data he obtained, he devoted a fair amount of space to contextualizing the human remains, which he later dealt with in a wide historical and archaeological context; he described not only the geography and language of the area but also the archaeology, making assertions about the social complexity of the inhabitants of Huarochiri in prehispanic times. ${ }^{6}$ In his osteoleogical analysis, Tello found signs of multiple exostosis in the parietal and frontal bones, which he attributed to syphilis. He also compared his sample of remains with data published on pre-Columbian skeletons from Tennessee, Kentucky, Bolivia, and Argentina to support his statements on the presence of syphilitic lesions in human bones.

It can be argued that Tello's osteological approach utilized the following train of thought:

(1) description of the cultural context of the osteological remains;

(2) comparative osteological descriptions from skulls from North America and South America;

(3) description of nine skulls retrieved from Huarochiri;

(4) analysis of probable syphilitic lesions in these nine skulls;

(5) comparison of these lesions with the North and South American specimens;

(6) analysis of pathologies described in the medical literature and comparisons with (3), (4), and (5);

(7) conclusions.

At the end of his work, Tello reached the following conclusions: (a) Ancient Andean languages contained the word huanthi, which was mostly a synonym of syphilis; (b) social practices may have induced the spread of the disease; (c) an ancient myth describes a 
venereal disease with symptoms similar to syphilis; (d) ceramic vessels show mutilations and lesions similar to those caused by syphilis; and (e) osteological lesions in prehispanic skulls seem to be caused by syphilis.

\section{Discussion}

Tello's method of testing the hypothesis that syphilis existed in the Andes prior to the Spaniards' arrival is an anthropological method. Taking evidence from linguistics, ethnography, archaeology and osteology, he was able to shed some light on the possible presence of syphilis in ancient Peru. I would like to separate the method itself from the evidence he presents. The linguistic evidence presented does not conclusively prove that the synonym for syphilis was part of the language before the Spanish arrived; although thought-provoking, it is not solid enough, since it only confirms the existence of a word used to describe a set of symptoms that might be related to other diseases (for example, leishmaniasis). It would be interesting to research the linguistic issue using modern evolutionary linguistic analysis to determine whether huanthi is in fact a prehispanic word.

The ethnographic evidence Tello provides is also inconclusive, since "promiscuous sexual practices" do not confirm the existence of the disease. Similarly, Tello's presentation of myths in which a sexual transmitted disease was present could have been strengthened; the case presented is interesting, but it is just a myth, and more cases would have solidified his claim.

Tello did a much better job dealing with the archaeological and osteological evidence. His identification of ceramic vessels showing syphilitic facial lesions (cranial caries sicca) seems solid, since he relied not only on his own expertise as a surgeon but also on the work of other researchers who had also identified syphilitic facial lesions in prehispanic ceramics. With regard to the osteological evidence, the sample size is too small, but the manifestations of syphilis are generally solid, with cranial caries sicca and multiple exostoses in the frontal and parietal bones seeming to indicate syphilis. It is curious that Tello opted not to include long bones in his analysis, since these can also present syphilis lesions (Baker et al., 1988), and one would expect to find syphilis lesions in the tibia of the skeletons from which the analyzed skulls were taken.

However, if we take these lines of evidence as individual pieces, the case regarding the presence of syphilis in the Andes prior to the arrival of the Spanish is not as strong as if we were to combine all the lines into a single argument. I believe that this was Tello's intention; his analysis could have included a larger sample size and further examination (particularly of the linguistic and ethnographic evidence), but I contend that his main contribution was the method he utilized. Tello combined the four subfields of anthropology and wrote the first serious work of medical anthropology in the Andes. According to the American Anthropological Association, medical anthropology

is a subfield of anthropology that draws upon social, cultural, biological, and linguistic anthropology to better understand those factors which influence health and wellbeing (broadly defined), the experience and distribution of illness, the prevention and treatment for sickness, healing processes, social relations of therapy management, and the cultural importance and utilization of pluralistic medical systems (AAA, s.d.). 
Although this definition is broad, it is precise enough to allow us to identify Tello's work as part of the subfield of medical anthropology.

Tello may have needed more evidence to consolidate his case, but in the end the most important issue is the method he used, a method that almost 108 years after its implementation is still being used and taught in anthropology.

\section{Legacy}

Tello's legacy is very straightforward, in the sense that he influenced the field of archaeology in the Central Andes and is still revered as a founding father of Peruvian archaeology (Burger, 2009; Kaulicke, 1994, 1998; Lumbreras, 2007; Mesia-Montenegro, 2006; Tantaleán, 2014). The otherwise static archaeological record became dynamic when other data and lines of evidence (ethnohistory and linguistics, for example) were added as contextual information for interpreting data (Tello, 1923, 1929, 1942). In this sense, Tello's legacy has been very well acknowledged.

But what about his influence in this particular subfield of medical anthropology? Or in the subfield of what is currently known as bioarchaeology? In describing Tello's 1909 approach, Lozada (2014, p.178) writes that he was "one of the first Peruvian scholars who studied human remains from archaeologically derived contexts and was sensitive to the cultural interpretation of his findings." A personal collaborator, Pedro Weiss (1956a), coined the term prehistoric epidemiology in reference to the study of prehispanic epidemiology. In 1955, he read the paper entitled Origen Americano de las Treponemiasis Sifilis - mal de pinto at the First Latin American Congress of Pathology in Mexico (Weiss, 1956b). Weiss's logic somewhat resembled Tello's, albeit more condensed, but he used long bones in addition to skulls and extensively quoted Tello's 1909 opus. Weiss was a close apprentice who traveled to Chavín de Huantar with Tello in 1919, and also had experience in the field of archaeology. Years later, he abandoned the term prehistoric epidemiology in favor of cultural osteology, which in his opinion referred to

the study of all bone alterations, intentional (deformations, trepanations, cauterizations etc.); environmental (changes due to nutritional, stressful or pathological reasons) or deceases (tumors, infections etc.), associated to the temporal framework, geographic area, tracing all possible associations with other indicators) (Weiss, 1961, p.135).

This definition was clearly influenced by Tello's work and the close relationship between the two scientists, and has been adopted by Andeanists in the field of bioarchaeology, if not strictly medical anthropology, a discipline which is not yet as extensive as archaeology in Peru. Weiss expressed Tello's anthropological approach when disregarding Imbelloni's (1925) classifications of cranial modification for a more culturally oriented approach (Weiss, 1962) that would fit ancient Peruvian practices, where "the taxonomies of cranial vault shaping borrowed heavily from ethnic divisions and horizons of Andean cultural evolution" (Tiesler, 2014, p.68). As Tiesler reported, Weiss's approach was espoused by different scholars (Allison et al., 1981; Lozada, 2011; Torres-Rouff, 2002) who adapted Weiss's views to examine aspects such ethnic composition, migration, and residence in 
their bioarchaeological approaches (Tiesler, 2014), and it can consequently be argued that Tello's legacy has been transmitted to bioarchaeologists through Weiss's work. Along the same lines, Verano and Lombardi (1999) recognize the contributions made by Tello and Weiss to the study of treponematosis while discussing paleopathology as a discipline in the Andes, defining it as the study of diseases in ancient populations.

With regard to the subfield of medical anthropology, it is possible to state that Lastres' $(1941,1951)$ monumental work on the history of Peruvian medicine and his quest for evidence of smallpox and tuberculosis in the work of Guamán Poma de Ayala was influenced by Tello's approach (if indirectly), since Lastres was Weiss's apprentice. Lastres worked closely with Pedro Cabieses (Lastres, Cabieses, 1959), who later "become instrumental to the future studies of human remains from archaeological contexts in the Andes" (Lozada, 2014, p.13); Cabieses (1974) later published a monumental study entitled Dioses y enfermedades: la medicina en el antiguo Perú which encompassed the archaeology, iconography, and ethnohistory of the prehispanic Andean world to reconstruct and retrace how medicine varied and was practiced in the ancient Andes. Tello's essence was very much alive in Cabieses' work, albeit indirectly.

This present paper began by evaluating Tello's method in his dissertation, La antigüedad de la sífilis en el antiguo Perú, as a precocious example of what later came to be called medical anthropology, and ends with a discussion of Tello's legacy and relevance. There is no doubt that Tello was clearly relevant to the development of Andean bioarchaeology, mainly due to the influence of Pedro Weiss, who transmitted Tello's method to future generations of Andeanists. Given the career path that Tello took after briefly practicing as a surgeon, it is understandable that most of his legacy has been assumed by archaeologists and bioarchaeologists rather than anthropologists.

Despite his logical reasoning with different lines of evidence, we must remember that Tello's dissertation was an academic product of the early twentieth century, a time with different rationales that led to the historical anachronism identified at the beginning of this paper. This anachronism actually proves how advanced Tello's logic was for his time, and explains the significant influence he had over future generations of Andean scholars exploring the prehispanic past through human bones or other archaeological remains. The case could even be made for a contextual approach to archaeology as early as the beginning of the twentieth century, but that is the subject for another essay.

\section{ACKNOWLEDGEMENTS}

I wish to thank the editors of História, Ciências, Saúde - Manguinhos, and the three anonymous reviewers whose comments greatly improved the quality of this paper.

\section{NOTES}

\footnotetext{
${ }^{1}$ In this and other citations of texto from non-english languages, a free translation has been provided.

${ }^{2}$ Tello mainly used early Spanish accounts that described behavior as well as cultural traditions among the people of the Andes.

${ }^{3}$ Many Andean civilizations mastered the art of anthropomorphic representations on ceramic surfaces.

${ }^{4}$ This was also accepted by Baker et al. (1988).
} 


\begin{abstract}
${ }^{5}$ Out of 4400, 229 cases analyzed by Fournier had a lesion in the nasal bone (5.2\% of the sample).
${ }^{6}$ Interestingly, Tello (1909, p.136) classified the native architecture of the area into three archaeological phases: a pre-Inca phase, an Inca phase, and a Spanish-influenced phase.
\end{abstract}

\section{REFERENCES}

AAA.

American Anthropological Association. What is medical anthropology? Available at: http:// www.medanthro.net/about/about-medicalanthropology/. Access on: 23 Mar. 2017. s.d.

ALLISON, Marvin et al.

La práctica de la deformación craneana entre los pueblos andinos precolombinos. Chungara, v.7, p.238-260. 1981.

ALTAMIRANO, Pedro.

Observaciones paleopatológicas a la tesis de Bachiller de Julio C. Tello Arqueología y Sociedad, n.26, p.71-90. 2013.

ARRIZABALAGA, Jon.

Medicina Universitaria y Morbus Gallicus en la Italia de finales del siglo XV: el Arquiatra Pontifico Gaspar Torrela (c.1452-c.1520). Asclepio, v.40, n.1, p.3-38. 1988.

ASHMEAD, Albert.

Testimony of the huacos (mummy-grave) potteries of old Peru. Proceedings of the American Philosophical Society, v.42, n.174, p.378-396. 1903.

AVILA, Francisco de.

Tratados y relación de errores, falsos dioses y otras supersticiones y ritos diabólicos en que vivían antiguamente los indios engañados de la provincia de Huarochirí, Mama y Chaclla, y hoy también viven engañados, con gran perdición de sus almas. In: Arguedas, José María; Duviols, Pierre.

Lima: Museo Nacional de Historia; Instituto de Estudios Peruanos. 1966.

BAKER, Brenda et al.

The origin and antiquity of syphilis: paleopathological diagnosis and interpretation [and comments and reply]. Current Anthropology, v.29, n.5, p.703-737. 1988.

BLONDIAUX, Joel; LE BAGOUSE, Alduc. A treponematosis dated from the Late Roman Empire in Normandie, France. In: Dutou, Olivier et al. (Org.) L'origine de la syphilis en Europe: avant ou apres 1493? Actes du colloque international de Toulon, 25-28 novembre 1993. Toulon: Centre archéologique du Var. p.99-100. 1994.

BURGER, Richard (Ed.).

The life and writings of Julio C. Tello: America's first indigenous archaeologist. Iowa City: University of Iowa Press. 2009.
CABIESES, Fernando.

Dioses y enfermedades: la medicina en el antiguo Perú. Lima: Artegraf. 1974.

COMELLES, Josep; MARTÍNEZ- HERNÁEZ, Ángel. Enfermedad, cultura y sociedad: un ensayo sobre las relaciones entre la antropología social y la medicina. Madrid: Eudema. 1993.

CROSBY, Alfred.

The early history of syphilis: a reappraisal.

American Anthropologist, v.71, n.2, p.218-227. 1969.

DENNIE, Charles.

A history of syphilis. Springfield: Thomas. 1962.

FOURNIER, Alfred.

Traité de la syphilis, periode tertiaire. v.2. Paris: Rueff. 1906.

HARPER, Kristin et al.

On the origin of the treponematoses: a phylogenetic approach. PLOS Neglected Tropical Diseases, v.2, n.1, p.1-13. 2008.

HARRISON, Lewis.

The origin of syphilis. The British journal of venereal diseases, v.35, n.1, p.1-7. 1959.

HENNEBERG, Maciej; HENNEBERG, Renata. Treponematosis in an Ancient Greek colony of Metaponto, southern Italy, 580-250 BCE. In: Dutou, Olivier et al. (Org.). L'origine de la syphilis en Europe: avant ou après 1493? Actes du colloque international de Toulon, 25-28 novembre 1993. Toulon: Centre archéologique du Var. p.92-99. 1994.

HERSHKOVITZ, I. et al.

Natural variation and differential diagnosis of skeletal changes in Bejel (endemic syphilis). In: Dutou, Olivier et al. (Org.). L'origine de la syphilis en Europe: avant ou après 1493? Actes du colloque international de Toulon, 25-28 novembre 1993. Toulon: Centre archéologique du Var. p.81-87. 1994.

HUDSON, Ellis.

Treponematosis and man's social evolution. American Anthropologist, v.67, n.4, p.885-901. 1965.

IMBELLONI, José.

Sobre el número de los tipos fundamentales a los que deben referirse las deformaciones craneanas de los pueblos indígenas de Sudamérica. Gaea: Anales de la Sociedad Argentina de Estudios Geográficos, tomo 1, parte 3, p.183-207. 1925. 
KAREM, Kevin; PILLAY, Allan.

On the origin of syphilis and contemporary views of disease dynamics. Journal of Ancient Diseases and Preventive Remedies, v.2, n.3, p.2-3. 2014.

KAULICKE, Peter.

Julio C. Tello vs. Max Uhle en la emergencia de la Arqueología peruana. In: Kaulicke, Peter (Ed.). Max Uhle y el Perú antiguo. Lima: Fondo Editorial de la Pontificia Universidad Católica del Perú. p.69-84. 1998.

\section{KAULICKE, Peter.}

Los orígenes de la civilización Andina: arqueología del Perú. Lima: Editorial Brasa. 1994.

KNELL, Robert.

Syphilis in Renaissance Europe: rapid evolution of an introduced sexually transmitted disease? Proceedings of the Royal Society of London B: Biological Sciences, v.271, suppl.4, p.S174-S176. 2004.

LASTRES, Juan.

Historia de la medicina peruana. Lima: Imprenta Santa María. 1951.

LASTRES, Juan.

La medicina en la obra de Guamán Poma de Ayala. Lima: Imprenta del Museo Nacional. 1941.

LASTRES, Juan; CABIESES, Fernando. Trepanación del cráneo en el antiguo Perú. Anales de la Facultad de Medicina, Universidad Nacional Mayor de San Marcos, v.42, n.3, p.258320. 1959.

LOPEZ DE VILLALOBOS, Francisco. El sumario de la medicina con un tratado sobre las pestíferas buvas. Salamanca: Universidad de Salamanca. 1498.

LOZADA, María Cecilia.

The emergence of bioarchaeology in Peru: origins and modern approaches. In: O’Donnabhain, Barra; Lozada Cerna, María Cecilia (Ed.). Archaeological human remains: global perspectives. New York: Springer. p.177187. 2014.

LOZADA, María.

Marking ethnicity through premortem cranial modification among the Pre-Inca Chiribaya, Perú. In: Bonogofsky, Michelle. The bioarchaeology of the human head: decapitation, decoration, and deformation. p.228-240. Florida: University of Florida Press. 2011.

LUGER, Anton.

The origin of syphilis: clinical and epidemiologic considerations on the Columbian theory. Sexually transmitted diseases, v.20, n.2, p.110-117. 1993.
LUMBRERAS, Luis.

Apuntes sobre Julio C. Tello, el Maestro. In: Julio C. Tello. Lima: Centro Cultural San Marcos, Museo de Arqueología y Antropología de la UNMSM. p.5-28. 2007.

MANTEGAZZA, Paolo.

L'amour dans l'humanité: essai d'une ethnologie de l'amour. Paris: F. Fetscherin et Chuit. 1886.

MESIA-MONTENEGRO, Christian.

Julio C. Tello: Teoría y práctica en la Arqueología andina. Arqueología y Sociedad, n.17, p.49-66. 2006.

PALFI, György et al.

Pre-olumbian congenital syphilis from the late antiquity in France. International Journal of Osteoarchaeology, v.2, n.3, p.245-261. 1992.

PARDAL, Ramón.

La medicina y la cirugía en la cerámica del antiguo Perú. Actas Ciba, n.7, p.207-217. jul. 1937.

POWELL, Mary; COOK, Della.

The myth of syphilis: the natural history of treponematosis in North America. Gainsville: University Press of Florida. 2005.

ROBERTS, Charlotte.

Treponematosis in Gloucester, England: a theoretical and practical approach to the preColumbian theory. In: Dutou, Olivier et al. (Org.) L'origine de la syphilis en Europe: avant ou après 1493? Actes du colloque international de Toulon, 25-28 novembre 1993. Toulon: Centre archéologique du Var. p.101-108. 1994.

ROTHSCHILD, Bruce.

History of syphilis. Clinical Infectious Diseases, v.40, n.10, p.1454-1463. 2005.

STIRLAND, Ann.

Pre-Columbian treponematosis in medieval Britain. International Journal of Osteoarchaeology, v.1, n.1, p.39-47. 1991.

TANTALEÁN, Henry.

Peruvian archaeology: a critical history. Walnut Creek, CA: Left Coast Press. 2014.

TELLO, Julio.

Origen y desarrollo de las civilizaciones prehistoricas andinas. [Reimpreso de las Actas del 27.

Congreso de Americanistas de 1939.] Lima: Gil. 1942.

TELLO, Julio. Antiguo Perú: primera época. 1929.

TELLO, Julio.

Wira Kocha. Inca, v.1, n.1, p.93-320. 1923. 
TELLO, Julio.

La antigüedad de la sífilis en el antiguo Perú. Tesis - Facultad de Medicina/Universidad Nacional Mayor de San Marcos, Lima. 1909.

TIESLER, Vera.

The bioarchaeology of artificial cranial modifications: new approaches to head shaping and its meanings in Pre-Columbian Mesoamerica and beyond. New York: Springer Science \& Business Media. 2014.

TOGNOTTI, Eugenia.

The rise and fall of syphilis in Renaissance Europe. Journal of Medical Humanities, v.30, n.2, p.99-113. 2009.

TORRES-ROUFF, Christina.

Cranial vault modification and ethnicity in middle horizon San Pedro de Atacama, Chile. Current Anthropology, v.43, n.1, p.163-171. 2002.

TRES...

Tres relaciones de antigüedades peruanas. Madrid: Ministerio de Fomento. 1879.
VERANO, John; LOMBARDI, Guido. Paleopatología en Sudamérica Andina. Bulletin de l'Institut français d'études andines, v.28, n.1, p.91-121. 1999.

WEISS, Pedro.

Tipología de las deformaciones cefálicas de los antiguos peruanos, según la osteología cultural. Revista del Museo Nacional, v.31, p.15-42. 1962.

WEISS, Pedro.

Osteología Cultural. 2do. Libro. Prácticas

Cefálicas: a) Deformaciones Intencionales de la Cabeza. b) Paleopatología. Anales de la Facultad de Medicina, v.44, n.2, p.133-276. 1961.

WEISS, Pedro.

Probable etiología palúdica de la

Espongiohiperostosis (Osteoporosis simétrica de Hrdlicka) que se encuentra en los cráneos de los antiguos peruanos. Anales de la Facultad de Medicina, v.39, n.3, p.1027-1036. 1956a.

WEISS, Pedro.

Origen americano de la treponemiasis sifilis mal de pinto. Revista Peruana de Ginecología y Obstetricia, v.2, n.1, p.41-68. 1956b. 